ということ起、最も一般的に日常使用される齿科用諸 材料数種について検討した。

\section{3. 歯牙病理発生に対する考え方の再検討}

病理 。浦鄉篤更、斉藤展之

諸種の外因意作用させて、その結果として起る歯牙 の発育あるい结成長化及ばす影響を観察するととは、 口腔病理学上では常識的であり、また口腔衛生学上極 めて重要な方法でもある。斯る歯牙病理発生学研究上 その基潗となる宷牙胎生学は睌に早くから一応完成さ れたものとして一般認められている。しかして現在 迄の䨑牙胎生学は、所謂胎生学として、あるいは生物 学として観察されてきた感があるので、吾々梳病理組 織学の立場汃らの再検討を試みた。教室では多数の人 胎览の口腔領域の梌索官行なっているが、その中で客 锥的に健康発育途上にあるべき胎児の霜牙に、今迄歯 科学的に病的であると思われて来た諸種の所見が常在 することを知った。今回は斯る諸事実堂提供し、批判 して戴き度い。

\section{4. 左側上顎骨に原発した所㯰 Kaposis Sarcoma（造血管細胞肉腫）と思われる 一剖検例}

$$
\begin{array}{r}
\text { 病 理 } 0 \text { 金子義郎、高野義臣 } \\
\text { 斉藤辰之、浦鄉篤史 } \\
\text { 口外竹 屋 昭 典 }
\end{array}
$$

造血管細胞肉腫の一型としての Kaposi の Sarcoma は、本邦にまだその報告例を見ない。本疾患は Sarcoma melanodes という名称で Hebra が 1868 年に報告し、その後 1872 年、Kaposi が Sarcoma idiopathicum Pigmentosum という名称を与光、 イタリアを中心とした西欧に多い皮虜科的な疾患であ るとされている。われわれは本大学附属病院を訪れた 33才男性の 1 例に接したが、主訴として左上顎曰霜部 左頓部、左眼窝部の疼痛を訴元、約数力月の経過後死 亡した一例繁剖検した結果、原発巣は左上顎曰崡部で あるようであり、肺、腎、副腎、膵、胃、大・小腸各 嶈膜面、腸間膜、横隔膜、右胸膜、大・小脳、皮蜀等 亿転移を見た。組織学的には不鮮明な管腔形成を示す 紡錘状細胞の増生即方血管中膜空残し内、外膜の極め て特徴的な異型堌殖を示す造血管細胞肉腫であり、 Kaposi の Sarcoma の一型であっても好いと思わ れる。

\section{5. 味蕾の変性に関する神経組織学的研究}

$$
\text { 口病上野正康、。北村勝也 }
$$

味蕾が味覚神経の未梢装置で味蕾と味覚神経との間 に特殊な相関々係の存するととは、先に演者の一人上 野が“味蕾の変性並びに再生に関する実験的研究”に 施いて味覚神経を切断すればそれの支配区域にある味 笛が殆んぞ完全に消失し、その切断端が接合されれば 再び味蕾の再生を見るというとと客実験的に証明し、 またその他の生理的実験によっても立証されている。 ところがてれらの事実を神経組織学的に赛付けした研 究は、吾々の渉猟せる範䦨では魚類（鯰）による Baoul M，May の報告觉見るのみである。そてで吾 々はてれを神経組織学的に立証せんがために上野が先 に行った実験方法と全く同様な方法によってラッテ味 覚神経、特に舌咽神経切断後に打ける有郭及び葉状の 両乳頭の神経及び味藿の変化について検索したのでそ の概要を報告する。

\section{6. （推）咀䂃初期における下顎運動路の精密測定 医持辛島 清 澄 \\ （九蒾学会誌 Vol. 14, No.2 参照）}

\section{7・眼窝底の埋伏歯を含む濾胞性粜牙囊胞の 2 例 口外。古本克磨、巨山保、馬渡和夫}

滤胞生菌牙襄胞は歯牙の発育時、または既に形成を 完了した理伏歯に関連して起る歯系連瘍の一型に属す る㵔溜性翼胞で、その報告は内外共に多く、枚挙にい とまがない程である。しかし上顎智柬に起因すると考 えられる該蒷胞の中で、埋伏崡か眼窩底部にあって、 てれる含むものの報告極めて稀である。

われわれは最近、埋伏智雪が眼窩底部にあって、て れに起因すると若えられる上顎牛側の大部を占める濾 胞性歯牙囊胞の極めて稀有な 2 例渑遇したので報告 する。

\section{8. 義菡性弁状增殖症の 1 例}

口多 。久原勝之、口病北村勝也、補皱 松浦智二

適合の良くない義歯床の辺緑々よる持続的機械的刺 戟によって歯肉乃至歯肉類移行部粘膜に弁状の尰瘍様 組織堌殖を来たすことがある。演者等は最近、64才の 女性で、約 25 年前に装着せるゴム床総義雪の刺戥によ って芯起された弁状堌殖症の 1 例に遭遇したので、こ こに報告する。 